\title{
Effects of Different Cooking Methods on Heavy Metals Level in Fresh and Smoked Game Meat
}

Kobia Joyce ${ }^{1}$, Emikpe BO ${ }^{2 *}$, Asare DA ${ }^{1}$, Asenso TN ${ }^{1}$, Yeboah Richmond ${ }^{3}$, Jarikre TA ${ }^{4}$ and Jagun-Jubril Afusat ${ }^{4}$

${ }^{1}$ Department of Animal Science, Kwame Nkrumah University of Science and Technology, Kumasi, Ghana

${ }^{2}$ Department of Pathobiology, School of Veterinary Medicine, Kwame Nkrumah University of Science and Technology, Kumasi, Ghana

${ }^{3}$ Department of Biological Sciences, Kwame Nkrumah University of Science and Technology, Kumasi, Ghana

${ }^{4}$ Department of Veterinary Pathology, Faculty of Veterinary Medicine, University of Ibadan, Nigeria

\begin{abstract}
This study investigated the effects of different cooking methods on heavy metals levels in fresh and smoked bush meat. Thirty-five fresh meat samples were washed thoroughly before employing the three different cooking methods (boiling, grilling and frying). Smoked meat samples obtained from central market were subjected to only boiling. Samples were protein digested and the digested solution was submitted to the Ghana Atomic Energy Commission for analysis. The Atomic Absorption Spectrometer was employed to detect the presence and concentration of heavy metal in game meats: (Iron ( $\mathrm{Fe})$, Copper (Cu), Cadmium (Cd), Lead $(\mathrm{Pb})$, Manganese $(\mathrm{Mn})$ and Zinc $(\mathrm{Zn})$ ). The data obtained was analyzed with a one- way analysis of variance. Results showed that different cooking methods had significant effect on heavy metals concentration with boiling increasing $\mathrm{Fe}, \mathrm{Pb}$, and $\mathrm{Cu}$ concentrations but reduced $\mathrm{Zn}$ (zinc) and $\mathrm{Mn}$ (manganese) concentration. Grilling increased $\mathrm{Fe}$ and $\mathrm{Cu}$ concentrations, but reduced $\mathrm{Pb}, \mathrm{Zn}$ and $\mathrm{Mn}$ concentrations. Frying decreased $\mathrm{Fe}, \mathrm{Cu}$ and $\mathrm{Mn}$ but increased $\mathrm{Zn}$ and $\mathrm{Pb}$ concentrations; lastly Cadmium (Cd) concentrations were within the recommended range and were not affected by any of the cooking methods. It is therefore recommended that consumers of game meat should be encouraged to subject fresh game meat to grilling which has the capacity to reduce the concentration of the most toxic heavy metal $(\mathrm{Pb})$. These findings shall inform measures in consumer safety.
\end{abstract}

Keywords: Bush meat; Heavy metals; Frying; Grilling; Boiling

\section{Introduction}

Wildlife is identified as a potential source of animal protein and income for rural households. Most rural populace hunts for bush meat for consumption as well as market some to earn money aside domestic animals such as chickens, sheep or goats. Bush meat refers to carcass of animals hunted from the wild [1]. The most commonly hunted bush meat animals are bats, squirrels, grasscutter, giant rats, guinea fowls and snakes [1]. These animals are regularly consumed only on ceremonial and festive occasions and not a regular source of food [2,3].

Studies show that carcass of grass cutter is widely recognized as a source of animal protein in Africa especially West Africa which has a large market for the meat [2]. In Ghana, bush meat is preferred to fish and other domestic animal's meat by the people of high social class [4]. The cane rat meat is appreciated because of its culinary properties with demand consistently outstripping supply [3,5]. Bush meat has an important nutritional role in the diet of humans; it adds diversity and encourages people to consume greater quantities of staple foods [6]. The demand for grasscutter meat has been met through hunting from the wild. This has been done by the use of guns, cutlasses, chase dogs, baiting with chemicals, and by bush burning [7]. The method of capture can pose a health threat to consumers because of the possibility of heavy metal contamination of the meat [8]. More so, the method of hunting is becoming a growing concern due to bullets containing $\mathrm{Pb}$ and other metals [9-11]. The use of guns as well as chemicals has been reported to have harmful effects on consumers and other untargeted species [7]. According to Omojola et al. [12], meat has the potential of accumulating toxic minerals and represents a major source of heavy metals for human consumption which poses as danger to animal and human health $[13,14]$.

The meat is often sold either as fresh (whole undressed) carcasses, or dressed and smoked $[3,15,16]$. Most people employ different cooking methods to process these meats and these methods include barbequing, boiling, grilling, pan frying, stir frying and roasting which is done to increase its flavor, taste, palatability and to make it tender [17]. Apart from the excellent taste, bush meat is nutritionally superior because of its higher protein and low fat level [18]. However, with the various cooking methods and their effects on palatability, there is a paucity of information on the effect on different cooking methods on heavy metals concentration in game animal meat. Therefore, this study attempts to evaluate the effect of different cooking methods on the heavy metals concentrations in fresh and smoked bush meat obtained in selected markets in Kumasi Ghana.

\section{Materials and Methods}

\section{Study area}

The study was carried out in Atwemunom Market and Central Market in the Kumasi Metropolis as well as parts of Sekyeredumase in the Ejura-Sekyedumase District within the Ashanti Region of Ghana. Sekyeredumase is located with latitude $6.747 \mathrm{~N}$ and longitude $-1.509 \mathrm{~W}$. The area is within the forest zone of Ghana characterized by high rainfall patterns and presence of forests and grasses which favor game animals such as grass cutter, giant rat, squirrels, and antelopes among others. The different kinds of bush meat available in these markets include both processed meat, fresh and smoked meat.

\section{Study animals}

Cane rat (Thryonomys swinderianus) and Giant rat were the study

*Corresponding author: Emikpe BO, Department of Pathobiology, School of Veterinary Medicine, Kwame Nkrumah University of Science and Technology, Kumasi, Ghana, Tel: +233549410841; E-mail: banabis2001@yahoo.com

Received July 29, 2016; Accepted August 18, 2016; Published August 24, 2016

Citation: Joyce K, Emikpe BO, Asare DA, Asenso TN, Richmond Y, et al. (2016) Effects of Different Cooking Methods on Heavy Metals Level in Fresh and Smoked Game Meat. J Food Process Technol 7: 617. doi: 10.4172/2157-7110.1000617

Copyright: (c) 2016 Joyce $\mathrm{K}$, et al. This is an open-access article distributed under the terms of the Creative Commons Attribution License, which permits unrestricted use, distribution, and reproduction in any medium, provided the original author and source are credited. 
animals considered because these were the mostly consumed bush meat in the area of this study. A total of thirty-five (35) bush meat samples were obtained, each weighing between 80 -130 grams of which five (5) were processed cane rat, fifteen (15) fresh cane rats and fifteen (15) fresh giant rat.

\section{Sample collection and preparation}

Fresh meat samples were analyzed and served as the standard. The muscles including the bones of the study cane rat and giant rat were distributed cautiously to three different cooking conditions of boiling, grilling, and frying. The meat was washed and boiled in a cooking pan with enough water to cover meat using gas stove. Again the processed meat of grass cutter was boiled; the processed meat was prepared as described by Omojola et al. [12]. All meat samples for grilling and frying were partially boiled for 5-8 minutes with water. No spices or food additives were added. Grilling of meat was done on a coal pot with charcoal fitted with metal grids for 10-15 minutes depending on the size of the meat. Frying of meat was carried out in a stainless frying pan containing vegetable cooking oil, it was fried for 3-5 minutes depending on this size and the temperature obtained was 170 degrees Celsius after frying. Fresh, boiled, fried and grilled meat samples were chopped into smaller parts and air-dried for 3-5 days to remove moisture. Air-dried meat samples were milled into powdery form using a blender.

\section{Laboratory analysis}

Digestion of samples and heavy metals detection: A gram (1 g) of each sample was weighed into a glass beaker for the digestion process. $10 \mathrm{ml}$ of nitric acid was added to it. A minimum time frame of two to five minutes was used to boil the samples on the stove which was then allowed to cool down for five to ten minutes. The digested samples were filtered using $50 \mathrm{ml}$ volumetric flasks, filter paper and a funnel. It was then topped up to $50 \mathrm{ml}$ using distilled water. Heavy metals concentrations of iron $(\mathrm{Fe})$, zinc $(\mathrm{Zn})$, copper $(\mathrm{Cu})$, manganese $(\mathrm{Mn})$, lead $(\mathrm{Pb})$ and cadmium $(\mathrm{Cd})$ were determined using the Atomic Absorption Spectrometer.

Statistical analysis: The results obtained were statistically analysed by SPSS Version 20 using one- way analysis of variance (ANOVA) and Duncan Multiple Range Test to find out the significant differences between cooking methods effects on heavy metals concentration. The presence or absence of a significant difference was specified at $95 \%$ confidence interval and significance level of $\mathrm{p}=0.05$.

\section{Results}

\section{Cooking methods effects on heavy metals concentration}

The result obtained for the effect of different cooking methods on the heavy metals concentration is represented in Table 1. Results obtained were compared to the accepted or safe limits levels of metal concentrations for human consumption. From Table 1, the average iron concentration in the fresh meat was $12.72 \mathrm{ppm}$; after employing the bush meat into the three cooking methods, boiling increased the iron concentration to $19.17 \mathrm{ppm}$, grilling increased the iron levels to $26.06 \mathrm{ppm}$. Frying bush meat reduced iron concentration level to $5.61 \mathrm{ppm}$. The average iron concentration for smoked bush meat, was $15.28 \mathrm{ppm}$ but concentration increased after boiling to $16.41 \mathrm{ppm}$. The average fresh meat concentration of manganese was $5.16 \mathrm{ppm}$ but after employing them into the three cooking methods, boiling reduced the manganese concentration to $0.64 \mathrm{ppm}$, frying reduced it $0.84 \mathrm{ppm}$ and grilling reduced it to $0.41 \mathrm{ppm}$. Copper concentration in the fresh state of the bush meat was $0.96 \mathrm{ppm}$. However, after boiling, the concentration increased to $1.09 \mathrm{ppm}$, frying reduced it to $0.56 \mathrm{ppm}$ and after grilling it increased to $1.99 \mathrm{ppm}$. Copper concentrations of smoked bush meat after boiling also increased from $0.94 \mathrm{ppm}$ to $1.24 \mathrm{ppm}$. Results also showed that boiling, grilling as well as boiling of smoked bush meat reduced the zinc concentrations of bush meat comparing to the fresh bush meat, however only fried bush meat increased the zinc concentrations from $7.40 \mathrm{ppm}$ to $7.64 \mathrm{ppm}$. Cadmium concentrations in the bush meat where not affected by the different cooking methods. The levels of cadmium concentration for the different cooking methods were the same as well as for the smoked and smoke-boiled bush meat (0.10). Concentration of lead in the fresh bush meat was $4.31 \mathrm{ppm}$. After boiling, it increased to $13.73 \mathrm{ppm}$ and increased to $17.32 \mathrm{ppm}$ after frying. The lead concentrations reduced drastically to $3.59 \mathrm{ppm}$ after grilling. In the smoked bush meat, initial lead concentration was $0.07 \mathrm{ppm}$ and it reduced to $0.05 \mathrm{ppm}$ after the smoked bush meat was boiled.

\section{Discussion}

This study was carried out to determine the extent of the effects of different cooking methods on heavy metals levels in fresh and processed (smoked) bush meat. From the results obtained, the average iron $(\mathrm{Fe})$ concentration for in the fresh meat was high above the recommended levels however after employing the three cooking methods, boiling increased the iron concentration, grilling increased the iron levels much higher $(\mathrm{p}<0.05)$ while frying reduced Fe concentration level. The average iron concentration for smoked bush meat was higher than the recommended level for human consumption but increased after boiling. This could be attributed to the interactions between the meat and the metal grid which is often made of iron. Therefore, during grilling, some of the Fe particles can get into the meat. This could have accounted for the higher Fe concentration in the grilled meat as well as for the smoked bush meat as they both employ the same processing procedure. In comparison of the results obtained to the accepted levels of iron $(\mathrm{Fe})$ concentration for human consumption (4.49 $\mathrm{ppm}$ to $15.0 \mathrm{ppm}$ ), none

\begin{tabular}{|c|c|c|c|c|c|c|}
\hline \multirow[b]{3}{*}{ Different cooking methods } & \multicolumn{6}{|c|}{ Heavy metals and their concentration levels (parts per million (ppm)) } \\
\hline & $\mathrm{Fe}$ & Mn & $\mathrm{Cu}$ & $\mathrm{Zn}$ & Cd & $\mathbf{P b}$ \\
\hline & Safe limits (4.49-15.0) & $\begin{array}{l}\text { Safe limits } \\
\text { (unknown) }\end{array}$ & Safe limits $(0.87-5.0)$ & Safe limits $(0.41-5.0)$ & Safe limits (0.33) & $\begin{array}{c}\text { Safe limits }(0.01- \\
0.38)\end{array}$ \\
\hline Fresh & 12.72 & 5.16 & 0.96 & 7.40 & 0.10 & 4.31 \\
\hline Boiled & 19.17 & 0.64 & 1.09 & 7.20 & 0.10 & 13.93 \\
\hline Fried & 5.61 & 0.84 & 0.56 & 7.64 & 0.10 & 17.32 \\
\hline Grilled & 26.06 & 0.41 & 1.99 & 6.97 & 0.10 & 3.59 \\
\hline Processed (fresh) & 15.28 & 5.33 & 0.94 & 7.39 & 0.10 & 0.07 \\
\hline Processed (Boiled) & 16.41 & 1.25 & 1.24 & 6.66 & 0.10 & 0.05 \\
\hline Significant level $(p<0.05)$ & 0.00 & 0.11 & 0.26 & 0.39 & 1.00 & 0.48 \\
\hline
\end{tabular}

Table 1: Effects of cooking methods on heavy metal concentrations in eat of bush meat. 
Citation: Joyce K, Emikpe BO, Asare DA, Asenso TN, Richmond Y, et al. (2016) Effects of Different Cooking Methods on Heavy Metals Level in Fresh and Smoked Game Meat. J Food Process Technol 7: 617. doi: 10.4172/2157-7110.1000617

of the cooking methods was able to reduce the iron concentrations and this may pose health hazards to humans.

The concentration of manganese in bush meat was reduced by the three cooking methods while smoked meat upon boiling reduced the manganese concentration. The reason for these findings has not been fully elucidated however this can be attributed to the possible effect of the heat treatments and water association of manganese.

Copper concentrations after boiling and grilling were increased while frying reduced it. Smoked bush meat upon boiling also increased the $\mathrm{Cu}$ concentrations from $0.94 \mathrm{ppm}$ to $1.24 \mathrm{ppm}$ however the concentration levels were within the recommended accepted levels of metal concentration for human consumption. This finding buttresses the report of Soewu et al. [19] who also reported that copper was detected in relative low quantities. Concentrations of lead in bush meat increased after boiling and after frying, however the concentrations reduced drastically when bush meat were grilled. Similar observation was noted in fresh and smoke-dried grasscutter (Thryonomys swinderianus Temminck) meat in Southern Nigeria [11]. In the smoked bush meat, the lead $(\mathrm{Pb})$ concentration was lower than that of the fresh and the different cooking methods and it reduced the more when it was boiled ( $p>0.05$ ). This can be attributed to the reduction of water in the meat as a result of the smoking and grilling of the meat which invariably could reduce the lead in the meat since lead is found mostly in the cytoplasm of the cell which reduced during smoking. The drop in concentration of heavy metal in the grilled samples were also corroborated in fish meat by Ahmed et al. [20], Eboh et al. [21], and Ajani et al. [22], attributed to heat effect on heavy metals and a possibility of the heavy metal being converted to other compounds. It was also reported that cooking methods (boiling, steaming, frying among others) can change the levels of toxic metals through various means, including the evaporation of water and volatile components, solubilization of the element and also by metal binding to other macronutrients present in the food item such as carbohydrates, lipids and proteins.

\section{Conclusion}

In conclusion, the different cooking methods had effects on the various heavy metals concentrations in bush meat. Iron $(\mathrm{Fe})$, zinc $(\mathrm{Zn})$ and manganese $(\mathrm{Zn})$ concentration is affected by the different cooking methods. In relation to lead $(\mathrm{Pb})$, frying and boiling increased the concentration level while grilling and smoking reduced the level of lead concentration in the meat to a considerable level. The concentration level of cadmium (Cd) was not affected by the different cooking methods. It can be recommended that bush meat should be smoked or grilled. These cooking methods have the capacity to reduce the concentration of lead $(\mathrm{Pb})$ considering its risk implications. These findings will help to inform measures in consumer safety.

\section{References}

1. Adeola M, Decker E (1987) Wildlife utilization in rural Nigeria. International Symposium of Wildlife Management in Sub-Saharan Africa.

2. Asibey E (1974) (Thryonomys Swinderianus) Temminck, in Ghana. The grasscutter 34: 161-170.

3. Ajayi S (1971) Wildlife as a source of protein in Nigeria; some priorities for development. Niger Field 36: 115-127.

4. Adomah YJC (2009) Features and profitability of domestic grasscutter production in the brong Ahafo region. University of Science and Technology, Kumasi-Ghana.

5. National Research Council (NRC) (1991) Little known small animals with a promising economic future. Micro-livestock.
6. Annegers J (1973) Seasonal food shortages in West Africa. Ecol Food Nutri 2: 251-257.

7. Oduro W, Kankam B (2002) Environmental and public health hazards of traditional grasscutter (Thryonomys Swinderianus) hunting. Proceedings of a workshop on promoting grasscutter production for poverty reduction in Ghana Pp: 19-22.

8. Hunt WG, Watson RT, Oaks LJ, Parish CN, Burnham KK, et al. (2009) Lead bullet fragments in venison from rifle-killed deer: Potential for human dietary exposure. PLoS ONE 4: e5330- e5330.

9. Irschik I, Bauer F, Sager M, Paulsen P (2012) Copper residues in meat from wild artiodactyls hunted with two types of rifle bullets manufactured from copper. Eur J Wildlife Res Eur J Wildlife Res.

10. AESAN (2012) Scientific committee risk associated with the presence of lead in wild game meat in Spain. Report approved by the Scientific Committee on plenary session.

11. Okoro KI, Igene JO, Ebabhamiegbebho PA, Evivie SE (2015) Lead (Pb) and Cadmium (Cd) levels in fresh and smoke-dried grasscutter (Thryonomys swinderianus Temminck) meat. Africa J Agri Res 10: 3116-3122.

12. Omojola A, Hammed S, Attoh-Kotoku V, Wogar-Gogar G, lyanda O, et al (2014) Physicochemical and organoleptic characteristics of Muscovy drake meat as influenced by cooking methods. Africa J Food Sci 8: 184-189.

13. Aschner M (2002) Neurotoxic mechanism of fish-bone methylmetry. Environ Toxicol Phamacol 12: 101-102.

14. Aycicek M, Kaplan M, Yarman M (2008) Effect of cadmium on germination seedling growth and metal contents of sunflower (Helianthus annus L). Asian Chem 20: 2663-2672.

15. Den Hartog A, DeVos A (1973) The use of rodents as food in tropical Africa FAO Nutr News 1: 1-4.

16. Barnes A (1994) A study FAO newsletter on traditional meat preservation technologies. Game animal meat drying in Ghana 5: 2-6.

17. Omojola AB, Ahmed SA, Attoh-Kotoku V, Wogar GS (2015) Effect of cooking methods on cholesterol, mineral composition and formation of total heterocyclic aromatic amines in Muscovy drake meat. J Sci Food Agric 95: 98-102.

18. Ledger $H$ (1963) Notes on the relative body composition of wild and domesticated ruminant. Bull Epizootic Dis Africa 2: 163-165.

19. Soewu DA, Bakare OK, Ayodele IA (2012) Trade in the wild mammalian species for traditional medicine in Ogun state, Nigeria. Global J Med Res 12: 6-21.

20. Ahmed A, Dodo A, Bouba AM, Clement S, Dzudie T, et al. (2011) Influence of traditional drying and smoke-drying on the quality of three fish species (Tilapia nilotica, Silurus glanis and Arius parkii) from Lagdo lake, Cameroon. J Anim Vet Adv 10: 301-306.

21. Eboh L, Mepba HD, Ekpo MB (2006) Heavy metal contaminants and processing effects on the composition, storage stability and fatty acid profiles of five common commercially available fish species in Oron local government, Nigeria. Food Chem 97: 490-497.

22. Ajani F, Adetuaji VO, Oyedokun JO (2013) Biophysiochemical changes that occur in fish during different stages of traditional processing. University of Ibadan, Nigeria. 